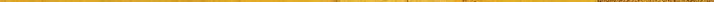




\section{Samuel Beckett and trauma}

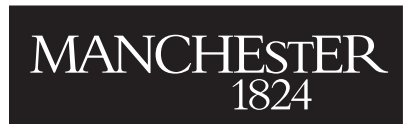

Manchester University Press 
Mariko Hori Tanaka, Yoshiki Tajiri, and Michiko Tshushima - 9781526121356 Downloaded from manchesterhive.com at 04/26/2023 10:09:19AM 


\title{
Samuel Beckett and trauma
}

\author{
EDITED BY MARIKO HORI TANAKA, \\ YOSHIKI TAJIRI AND MICHIKO TSUSHIMA
}

Manchester University Press 
Copyright $\odot$ Manchester University Press 2018

While copyright in the volume as a whole is vested in Manchester University Press, copyright in individual chapters belongs to their respective authors, and no chapter may be reproduced wholly or in part without the express permission in writing of both author and publisher.

Published by Manchester University Press

Altrincham Street, Manchester M1 7JA

www.manchesteruniversitypress.co.uk

British Library Cataloguing-in-Publication Data

A catalogue record for this book is available from the British Library

ISBN 9781526121349 hardback

First published 2018

The publisher has no responsibility for the persistence or accuracy of URLs for any external or third-party internet websites referred to in this book, and does not guarantee that any content on such websites is, or will remain, accurate or appropriate.

Typeset in Minion by

Servis Filmsetting Ltd, Stockport, Cheshire 